\title{
$\square$
}

\section{The Microfinance Revolution: An Overview}

\author{
Rajdeep Sengupta and Craig P. Aubuchon
}

\begin{abstract}
The Nobel Prize committee awarded the 2006 Nobel Peace Prize to Muhammad Yunus and the Grameen Bank "for their efforts to create economic and social development from below." The microfinance revolution has come a long way since Yunus first provided financing to the poor in Bangladesh. The committee has recognized microfinance as "an important liberating force" and an "ever more important instrument in the struggle against poverty." Although several authors have provided comprehensive surveys of microfinance, our aim is somewhat more modest: This article is intended as a non-technical overview on the growth and development of microcredit and microfinance. (JEL I3, J41, N80)
\end{abstract}

Federal Reserve Bank of St. Louis Review, January/February 2008, 90(1), pp. 9-30.

n 2006, the Grameen Bank and its founder Muhammad Yunus were awarded the Nobel Peace Prize for their efforts to reduce poverty in Bangladesh. By providing small loans to the extremely poor, the Grameen Bank offers these recipients the chance to become entrepreneurs and earn sufficiently high income to break themselves free from the cycle of poverty. Yunus's pioneering efforts have brought renewed attention to the field of microfinance as a tool to eliminate poverty; and, since 1976 when he first lent $\$ 27$ to 42 stool makers, the Grameen Bank has grown to include more than 5.5 million members with greater than $\$ 5.2$ billion in dispersed loans. As microfinance institutions continue to grow and expand, in both the developing and developed world, social activists and financial investors alike have begun to take notice. In this article we seek to explain the rise in microfinance since its inception in the early 1980s and the various mechanisms that make microfinance an effective tool in reducing poverty. ${ }^{1}$ We also address the current problems facing microfinance and areas for future growth.
In its broadest sense, microcredit includes the act of providing loans of small amounts, often $\$ 100$ or less, to the poor and other borrowers that have been ignored by commercial banks; under this definition, microcredit encompasses all lenders, including the formal participants (such as specialized credit cooperatives set up by the government for the provision of rural credit) and those of a more informal variety (such as the village moneylender or even loan sharks). Yunus (2007) argues that it is important to distinguish microcredit in all its previous forms from the specific form of credit adopted at the Grameen Bank, which he calls "Grameencredit." Yunus argues that the "most distinctive feature of Grameencredit is that it is not based on any collateral, or legally enforceable contracts. It is based on 'trust,' not on legal procedures and system." For the purposes of this article and unless mentioned otherwise, our use of the term microcredit

1 Other, more technical surveys of microfinance include Ghatak and Guinnane (1999), Morduch (1999), and Armendáriz de Aghion and Morduch (2005).

Rajdeep Sengupta is an economist and Craig P. Aubuchon is a research associate at the Federal Reserve Bank of St. Louis. The authors thank Subhayu Bandyopadhyay, Patrick Pintus, and George Fortier for helpful comments and suggestions.

C 2008, The Federal Reserve Bank of St. Louis. Articles may be reprinted, reproduced, published, distributed, displayed, and transmitted in their entirety if copyright notice, author name(s), and full citation are included. Abstracts, synopses, and other derivative works may be made only with prior written permission of the Federal Reserve Bank of St. Louis. 
will, for the most part, follow Yunus's characterization of Grameencredit.

Although the terms microcredit and microfinance are often used interchangeably, it is important to recognize the distinction between the two. As mentioned before, microcredit refers to the act of providing the loan. Microfinance, on the other hand, is the act of providing these same borrowers with financial services, such as savings institutions and insurance policies. In short, microfinance encompasses the field of microcredit. Currently, it is estimated that anywhere from 1,000 to 2,500 microfinance institutions (MFIs) serve some 67.6 million clients in over 100 different countries. ${ }^{2}$

Many MFIs have a dual mandate to provide financial as well as social services, such as health care and educational services for the underprivileged. In this sense, they are not always perceived as profit-maximizing financial institutions. At the same time, the remarkable accomplishment of microfinance lies in the fact that some of the successful MFIs report high rates of repayment, sometimes above 95 percent. This rate demonstrates that lending to underprivileged borrowers-those without credit histories or the assets to post collateral—can be a financially sustainable venture.

Not surprisingly, philanthropy is not a requirement of microfinance-not all MFIs are non-profit organizations. While MFIs such as Banco Sol of Bolivia operate with the intent to return a profit, other MFIs like the Grameen Bank charge below-market rates to promote social equity. ${ }^{3}$ As will be discussed below, this distinction is important: As the microfinance industry continues to grow and MFIs serve a wider client base, the commercial viability of an MFI is often viewed as crucial for its access to more mainstream sources of finance. (We will return to this and related queries in the "The Evidence of

2 Microfinance Information Exchange (MIX) lists financial profiles and data for 973 MFIs. The high estimate of 2,500 comes from a survey conducted by the Microcredit Summit Campaign in 2002.

3 The social objectives of the Grameen Bank are summarized by the 16 decisions in their mission statement. The statement is available at http://grameen-info.org/bank/the16.html.
Microfinance" section of this paper.) The next section offers a brief history of the Grameen Bank and a discussion of its premier innovation of group lending contracts; the following sections describe the current state of microfinance and provide a review of some of the common perceptions on microfinance. The final section outlines the future of microfinance, particularly in the context of global capital markets.

\section{A BRIEF HISTORY OF THE GRAMEEN BANK}

The story of the Grameen Bank is a suitable point to begin a discussion of microcredit and microfinance. After obtaining a $\mathrm{PhD}$ in economics in 1969 and then teaching in the United States for a few years, Muhammad Yunus returned to Bangladesh in 1972. Following its independence from Pakistan in 1971 and two years of flooding, Bangladesh found itself in the grips of a terrible famine. By 1974, over 80 percent of the population was living in abject poverty (Yunus, 2003). Yunus, then a professor of economics at Chittagong University in southeast Bangladesh, became disillusioned with economics: "Nothing in the economic theories I taught reflected the life around me. How could I go on telling my students make believe stories in the name of economics?" (See Yunus, 2003, p. viii.) He ventured into the nearby village of Jobra to learn from the poor what causes their poverty. Yunus soon realized that it was their lack of access to credit that held them in poverty. Hence, the origins of "microfinance" emerged from this experience when Yunus lent $\$ 27$ of his own money to 42 women involved in the manufacturing of bamboo stools. ${ }^{4}$

\footnotetext{
4 Yunus (2003) describes his conversation with Sufiya, a stool maker. She had no money to buy the bamboo for her stools. Instead, she was forced to buy the raw materials and sell her stools through the same middleman. After extracting interest on the loan that Sufiya used to buy the bamboo that morning, the moneylender left her with a profit of only 2 cents for the day. Sufiya was poor not for lack of work or skills, but because she lacked the necessary credit to break free from a moneylender. With the help of a graduate student, Yunus surveyed Jobra and found 41 other women just like Sufiya. Disillusioned by the poverty around him and questioning what could be done, Yunus lent $\$ 27$ dollars to these 42 women and asked that he be repaid whenever they could afford it.
} 


\section{Figure 1}

\section{Grameen Bank Membership}

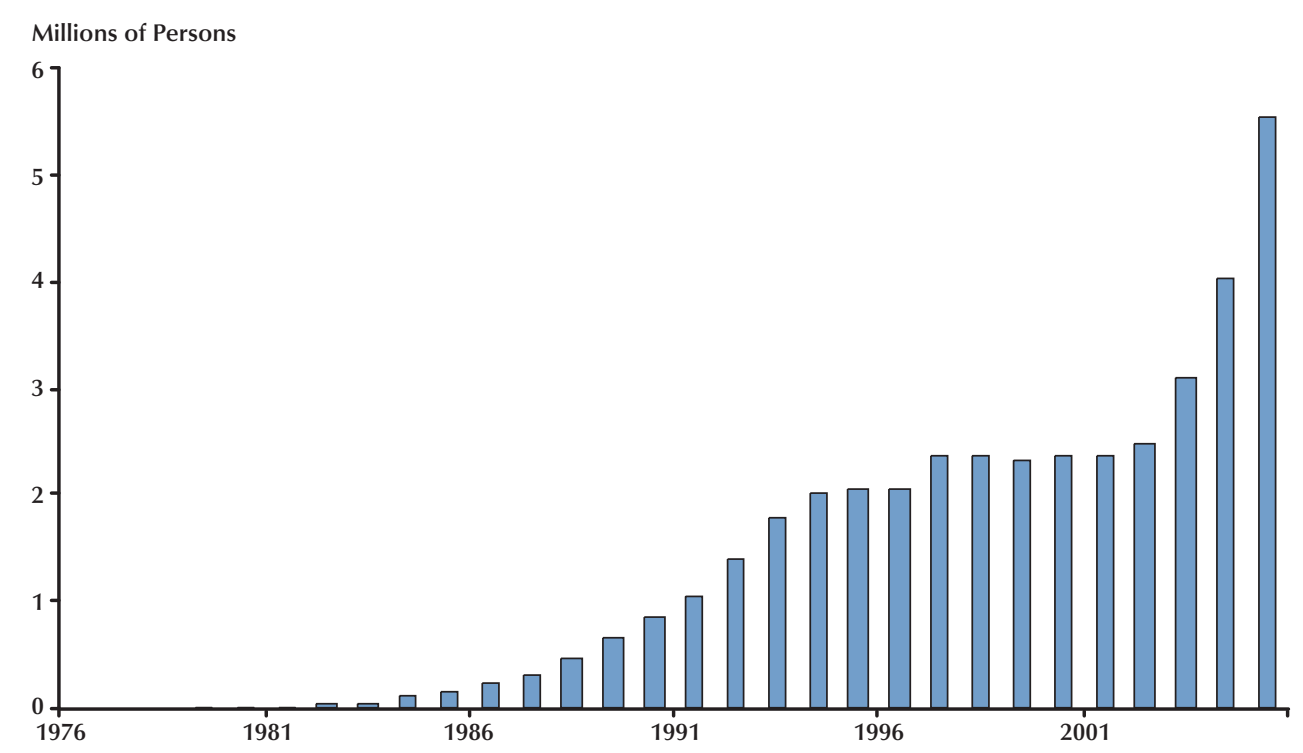

Through a series of trials and errors, Yunus settled on a working model and by 1983, under a special charter from the Bangladesh government, founded the Grameen Bank as a formal and independent financial institution. Grameen is derived from the Bengali word gram, which means village; grameen literally means "of the village," an appropriate name for a lending institution that requires the cooperation of the villagers. The Grameen Bank targets the poor, with the goal of lending primarily to women. Since its inception, the Grameen Bank has experienced high growth rates and now has more than 5.5 million members (see Figure 1), more than 95 percent of whom are women. ${ }^{5}$

Lending to poor villagers involves a significant credit risk because the poor are believed to be uncreditworthy: That is, they lack the skills or the expertise needed to put the borrowed funds to their best possible use. Consequently, mainstream banks have for the most part denied

${ }^{5}$ Grameen Bank, annual reports (various years). Data can be viewed at www.grameen-info.org/annualreport/commonElements/htmls/ index.html. the poor access to credit. The Grameen Bank has challenged decades of thinking and received wisdom on lending to the poor. It has successfully demonstrated this in two ways: First, it has shown that poor households can benefit from greater access to credit and that the provision of credit can be an effective tool for poverty alleviation. Second, it has proven that institutions do not necessarily suffer heavy losses from lending to the poor. An obvious question, though, is how the Grameen Bank succeeded where so many others have failed. The answer, according to most economists, lies in its unique group lending contracts, which enabled the Grameen Bank to ensure repayment without requiring collateral from the poor.

\section{The Group Lending Innovation}

This Grameen Bank lending model can be described as follows: Borrowers organize themselves into a group of five and present themselves to the Bank. After agreeing to the Bank rules, the first two members of the group receive a loan. If the first two successfully repay their loans, then 
four to six weeks later the next two are offered loans; after another four to six weeks, the last person is finally offered a loan. As long as all members in the group repay their loans, the promise of future credit is extended. If any member of the group defaults on a loan, then all members are denied access to future credit. Furthermore, eight groups of Grameen borrowers are organized into centers and repayment is collected during public meetings. While this ensures transparency, any borrower who defaults is visible to the entire village, which imposes a sense of shame. In rural Bangladesh, this societal pressure is a strong disincentive to default on the loan. Initial loans are small, generally less than $\$ 100$, and require weekly repayments that amount to a rate of 10 percent per annum. ${ }^{6}$ Weekly repayments give the borrowers and lenders the added benefit of discovering problems early.

Group lending_or the joint liability contract-is the most celebrated lending innovation by the Grameen Bank. Economies of scale motivated its first use, and Yunus later found that the benefits of group lending were manifold. Under a joint liability contract, the members within the group (who are typically neighbors in the village) can help mitigate the problems that an outside lender would face. Outside lenders such as banks and government-sponsored agencies face what economists call agency costs. For example, they cannot ensure that the borrowed money be put to its most productive use (moral hazard), cannot verify success or failure of the proposed business (costly state verification/auditing), and cannot enforce repayment. It is not difficult to see how peers within the group can help reduce these costs, particularly in a situation where the promise of future credit depends on the timely repayment of all members in the group. Joint liability lending thus transfers these agency costs from the bank onto the community of borrowers, who can provide the same services more efficiently.

But perhaps the more difficult agency problem faced by lenders is that of adverse selectionascertaining the potential credit risk of the

6 See www.grameen-info.org/bank/GBGlance.htm. Other sources put the annual rates charged by MFIs at around 30 to 60 percent. borrower. Market failure occurs because safe borrowers (who are more likely to repay) have to subsidize risky borrowers (who are more likely to default). Because the bank cannot tell a safe borrower from a risky one, it has to charge the same rate to all borrowers. The rate depends on the mix of safe and risky borrowers in the population. When the proportion of risky borrowers is sufficiently large, the subsidy required (for the lender to break even on all borrowers) is so high that the lender has to charge all borrowers a significantly high rate. If the rates are sufficiently high, safe borrowers are unlikely to apply for a loan, thereby adversely affecting the composition of the borrower pool. In extreme cases, this could lead to market failure-a situation in which lenders do not offer loans because only the risky types remain in the market!

Economic theory helps show how joint liability contracts mitigate adverse selection (Ghatak and Guinnane, 1999). Under group lending, borrowers choose their own groups. A direct way in which this might help is when a prospective customer directly informs the bank about the reliability of potential joiners. Perhaps a more surprising result is that the lender can mitigate the adverse selection problem even when customers do not directly inform the bank but form themselves into like groups (peer selection). That is, given a joint liability clause, safe customers will more likely group together with other safe customers, leaving the risky types to form groups by themselves. This "assortative matching" mitigates the adverse selection problem because now the risky borrowers are the ones who must bail out other risky borrowers, while the safe borrowers have to shoulder a lesser subsidy. Consequently, all borrowers can be charged a lower rate, reducing the likelihood of a market failure.

\section{CURRENT STATE OF MICROFINANCE}

Since the inception of the Grameen Bank, microfinance has spread to cover five continents and numerous countries. The Grameen Bank has 


\section{Figure 2}

\section{Savings by Region}

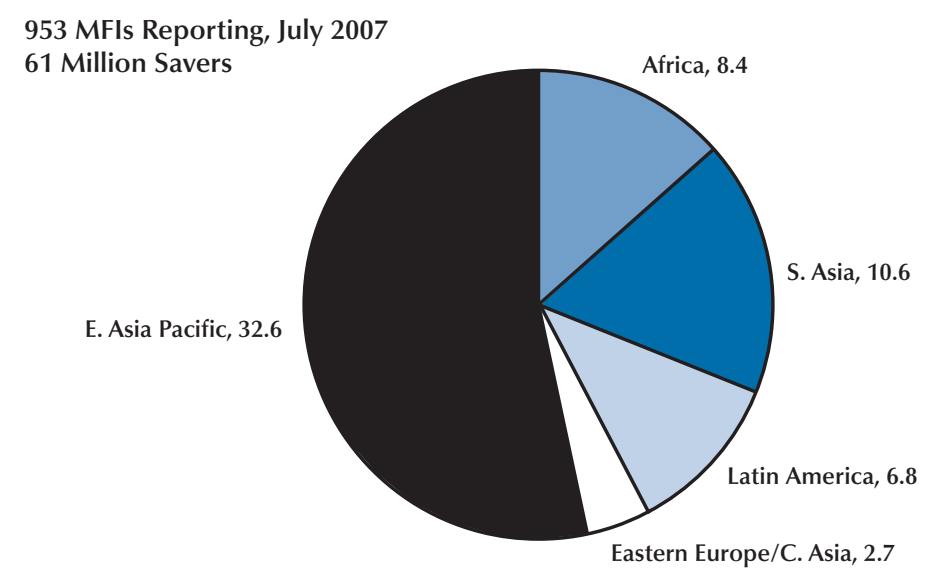

SOURCE: Microfinance Information Exchange Network; www.mixmarket.org.

been duplicated in Bolivia, Chile, China, Ethiopia, Honduras, India, Malaysia, Mali, the Philippines, Sri Lanka, Tanzania, Thailand, the United States, and Vietnam; the microfinance information exchange market (MIX) lists financial information for 973 MFIs in 105 different countries. Some MFIs have also begun to seek out public and international financing, further increasing their amount of working capital and expanding the scope of their operations. As MFIs have become more efficient and increased their client base, they have begun to expand their services through different product offerings such as micro-savings, flexible loan repayment, and insurance. We discuss these three different product offerings below.

At the time of their inception, many MFIs included a compulsory savings component that limited a borrower's access to deposited funds. This promoted long-term savings, but ignored the fact that many poor save for the short term to smooth consumption during seasonal lows of production. Figure 2 provides a look at the distribution of voluntary MFI savings by region. As MFIs have become better versed in the microfinance market, they have applied their innovations in lending to the collection of deposits. One of the leading examples is SafeSave, located in Dhaka,
Bangladesh, which uses the idea that frequent small deposits will guard against the temptation of spending excess income. To keep the transaction costs of daily deposits low, SafeSave hires poor workers from within the collection areas (typically urban slums) to meet with clients on a daily basis. By coming to the client, SafeSave makes it convenient for households to save; by hiring individuals from the given area, training costs and wages are also kept low. With this efficient model for both the bank and individuals, SafeSave has accumulated over 7,000 clients in six years. ${ }^{7}$ Not surprisingly, microfinance deposits (like microfinance loans) break from traditional commercial banking experiences. The example of Bank Rakyat Indonesia (BRI) suggests that the poor often value higher liquidity over higher interest rates on deposit products. In 1986, after a year of field experiments, they offered two deposit products: The TABANAS product offered a 12 percent interest rate but restricted withdrawals to twice monthly, whereas the SIMPEDES product offered an interest rate of zero but allowed unlimited withdrawals. The SIMPEDES program saw the largest gain in popularity and to this day

7 See www.savesafe.org. 
still offers a lower interest rate but maintains more accounts than the TABANAS program. ${ }^{8}$

The original Grameen Bank was one of the first MFIs that incorporated a compulsory savings requirement into their lending structure. Every client was required to make a deposit worth 5 percent of their given loan, which was placed into a group fund with strict withdrawal rules (generally no withdrawals before three years). In 2001, the Grameen Bank reviewed both its lending and savings policy and reinvented itself as Grameen II. At the heart of this change were more savings options and more flexible loans, which act as a form of insurance. New to Grameen II is a pension fund, which allows clients with loans greater than 8,000 taka (\$138) to contribute at least 50 taka (\$0.86) per month. The client receives 12 percent per year in compound interest, earning a 187 percent return after the mandatory 10-year wait. This scheme allows Grameen II to earn more money in the present and expand services, while delaying payment in the near future.

Grameen II serves as a good example of a second innovation in microfinance: flexible loan repayment. Group lending still exists and is an integral part of the process, but Grameen II introduced a flexi-loan that allows borrowers multiple options to repay their loan on an individual basis. Yunus (2002) stated that "group solidarity is used for forward-looking joint actions for building things for the future, rather than for the unpleasant task of putting unfriendly pressure on a friend." The flexi-loan is based on the assumption that the poor will always pay back a loan and thus allows the poor to reschedule their loan during difficult periods without defaulting. If the borrower repays as promised, then the flexiloan operates exactly like the basic loan, using dynamic incentives ${ }^{9}$ to increase the size of the loan after each period. If the borrower cannot make her payments, she is allowed to renegotiate her loan contract rather than default. She can

8 The SIMPEDES program does also use a lottery system to give rewards, often worth 0.7 percent of deposits. More details are available at the BRI web page: www.bri.co.id/english/mikrobanking/aboutmikrobanking.aspx.

9 Dynamic incentives threaten to exclude defaulted borrowers from future loans. either extend the life of the loan or pay only the principle for an extended period of time. As a penalty, the dynamic incentives of her loan are reset; she cannot access larger (additional) amounts of credit until the original loan is repaid. Because her default now poses no threat to the group promise of future credit, each member is accountable only up to their individual liabilities.

The third offering is the addition of insurance to microfinance loans. The most basic insurance is debt relief for the death of a borrower, offered by many MFIs, including Grameen. Other MFIs have begun experimenting with health insurance and natural disaster insurance. As with lending, agency problems present a dilemma for microinsurance. To this end, some groups such as FINCA Uganda require life insurance of all borrowers, including "risky" and "healthy" alike and thus avoid the adverse selection problem. Other ideas include providing rain insurance to guard against catastrophes. This relies on the assumption that crop yields (and much of the developing economy) are tied to seasonal rain cycles. This innovation eliminates the problem of moral hazard associated with a crop loan. By tying performance to rain cycles, a farmer has no incentive to take crop insurance and then fail to adequately produce a crop during a season of adequate rainfall.

A more recent phenomenon in microfinance is the emergence of foreign investment in MFIs. As more and more MFIs establish positive returns, microfinance is being seen by many professional investors as a profitable investment opportunity. One of the most important developments for the MFIs was the June 2007 release of Standard \& Poor's (S\&P) report on the rating methodology for MFIs. By applying a common methodology, $\mathrm{S} \& \mathrm{P}$ will be able to send a stronger signal to potential investors about the quality of MFI investments. The process of debt offerings and securitization in the microfinance sector will be covered in greater detail below.

\section{MICROFINANCE AROUND THE WORLD}

As Yunus and the Grameen Bank began to prove that microfinance is a viable method to 


\section{Table 1}

\section{Characteristics of Select Microfinance Institutions}

\begin{tabular}{|c|c|c|c|c|}
\hline & $\begin{array}{c}\text { Grameen Bank, } \\
\text { Bangladesh }\end{array}$ & $\begin{array}{c}\text { Banco Sol, } \\
\text { Bolivia }\end{array}$ & $\begin{array}{c}\text { Compartamos, } \\
\text { Mexico }\end{array}$ & $\begin{array}{c}\text { Enterprise } \\
\text { Development Group, } \\
\text { Washington, D.C. }\end{array}$ \\
\hline Established & 1983 & 1992 & 1990 & 1993 \\
\hline Membership & $6,948,685$ & 103,786 & 616,528 & 250 \\
\hline Average loan balance (US\$) & $\$ 69$ & $\$ 1,571$ & $\$ 440$ & $\$ 22,285^{* *}$ \\
\hline Percent female & $96.70 \%$ & $46.40 \%$ & $98.40 \%$ & $30.00 \%$ \\
\hline Group lending contracts? & Yes & Yes & Yes & No \\
\hline Collateral required? & No & No & No & No \\
\hline Portfolio at risk $>30$ days ratio & $1.92 \%$ & $2.91 \%$ & $1.13 \%$ & N/A \\
\hline Return on equity & $1.95 \% *$ & $22.81 \%$ & $57.35 \%$ & $\mathrm{~N} / \mathrm{A}$ \\
\hline Operational self-sufficiency & $102.24 \% *$ & $120.09 \%$ & $181.22 \%$ & $53 \% * *$ \\
\hline \multicolumn{5}{|l|}{ NOTE: *12/31/2005; **2004. } \\
\hline \multicolumn{5}{|c|}{$\begin{array}{l}\text { SOURCE: Data for this table come from the Microfinance Information Exchange (MIX) Network, which is a web-based platform: } \\
\text { www.mixmarket.org. Information was provided for the Enterprise Development Group because it is the only U.S.-based MFI that } \\
\text { reports data on the MIX network. Some of the information for EDG was taken from their 2003/2004 annual report, available at } \\
\text { www.entdevgroup.org. Comparable information is not available for the Southern Good Faith Fund, as the scope of their mission has } \\
\text { changed and expanded to more training-based programs. A more comprehensive summary chart exists in Morduch (1999). }\end{array}$} \\
\hline
\end{tabular}

alleviate poverty, their methodology and program began to spread around the world. It is difficult to know exactly how many MFIs there currently are, but Microfinance Information Exchange (MIX) estimates range from 1,000 to 2,500 serving some 67.6 million clients. Of these 67 million, more than half of them come from the bottom 50 percent of people living below the poverty line. That is, some 41.6 million of the poorest people in the world have been reached by MFIs. MFIs have expanded their operations into five different continents and penetrated both rural and urban markets. They have achieved success with a variety of credit products and collection mechanisms. Table 1 provides a comparison of several groups from around the world.

\section{Banco Solidario (Bolivia)}

Banco Solidario originally existed as the Fundacion para Promocion y el Desarrollo de la Microempresa (PRODEM), a non-governmental organization (NGO) in the mid-to-late 1980s and provided small capital loans to groups of three or more people dedicated to entrepreneurial activities. By 1992, PRODEM serviced 17,000 clients and disbursed funds totaling \$4 million dollars. Constrained by the legal and financial regulations governing an NGO, the board of directors decided to expand their services and PRODEM became the commercial bank, Banco Solidario, later that year. Currently, Banco Sol has 48 branches in seven cities with over 110,000 clients and a loan portfolio of more than $\$ 172$ million. As of March 31, 2007, Banco Sol reported a past-due loans level of only 1.78 percent. An important distinction between Grameen and Banco Sol is the latter's emphasis on returning a profit with poverty alleviation stated only as a secondary goal.

Banco Sol offers credit, savings, and a variety of insurance products. Their initial loan offering was based on Grameen-style joint-liability lending, offering a maximum of $\$ 3,000$ per client to groups of three or four individuals with at least one year of experience in their proposed occupation. Using dynamic incentives, the size of the loan is gradually increased based on good repayment history. Annual interest rates average 
between 12 and 24 percent and can be anywhere from 1 to 60 months in length (120 months for a housing loan). ${ }^{10}$ With these higher interest rates, Banco Sol does not rely on subsidies and, at the end of 2006, posted returns on equity of 22.8 percent.

\section{Compartamos (Mexico)}

Compartamos is the largest MFI in Mexico, servicing some 630,000 clients with an active loan portfolio of $\$ 285$ million. Located in Mexico City, Compartamos is active in 26 Mexican states throughout the country and services primarily rural borrowers. Compartamos was founded in 1990 and began by offering joint-liability loans to female borrowers for income-generating activities. Compartamos has only recently expanded their services to allow men to borrow through their solidarity group and their individual credit program; still, around 98 percent of their borrowers are female. In 1998, Compartamos formed a strategic alliance with Accion International and transformed into a regulated financial institution, called a Sociedad Financiera de Objeto Limitado (SFOL). In 2002, Compartamos took a unique step for a MFI and became one of the first MFIs to issue public debt, listing themselves on the Mexican Stock Exchange. As an SFOL, Compartamos was limited to only offering credit for working capital. In order to offer more services, such as savings and insurance programs, Compartamos became a commercial bank in 2006.

Compartamos was one of the first MFIs to raise additional capital funds through the sale of domestic bond issuances. In 2002, Compartamos was the first MFI in Mexico and one of the first in Latin America to offer a bond sale. Because this was Standard and Poor's first attempt at rating a microfinance bond, they adapted their current methodology and rated the bond using their Mexican scale and assumed local buyers. S\&P was impressed with the diversified portfolio of debt and offered Compartamos an MXA+ (Mexican AA) rating. Reddy and Rhyne (2006) report that their most recent bond was rated an MXAA

\footnotetext{
${ }^{10}$ Banco Sol, accessed July 27, 2007; www.bancosol.com.bo/en/ intro.html.
}

through the use of credit enhancements, allowing them to place the bond with institutional investors. Their fifth issue to date was three times oversubscribed with 70 percent of the bond purchased by institutional investors. By accessing the commercial market, Compartamos has been able to lower the cost of obtaining funds and, in turn, offer better services to their borrowers, such as absorbing the costs of providing life insurance for all clients. Their efforts to improve operational efficiency have also created a self-sufficient MFI that has existed without subsidies for over a decade.

\section{Good Faith Fund (United States)}

The Good Faith Fund was modeled after the Grameen Bank and was one of the first MFIs to be established in America. In 1986, while governor of Arkansas, Bill Clinton invited Muhammad Yunus to visit and discuss microfinance. The initial program was started as the Grameen Fund, but the name was later changed to better reflect the fund's commitment to providing loans to micro-entrepreneurs. Loans weren't securitized with collateral; rather, they were guaranteed on "good faith" (Yunus, 2003, p.180).

As the Good Faith Fund grew, practitioners and academics alike began to question the effectiveness of a pure Grameen-style program in the United States. Much like the original Grameen Bank, the Good Faith Fund has relied on innovation and change to apply microlending to the rural economy of Arkansas. Taub (1998) argues that the Good Faith Fund is a successful poverty alleviation program, but that it is a poor economic development program. In Taub's words, "the Good Faith Fund has never been able to deliver a meaningful volume of customers, provide substantial loan services to the really poor, or achieve anything close to institutional selfsufficiency." He argues that important social differences arise because rural Arkansas is inherently different from rural Bangladesh and that these social differences cause the group lending model to fail.

Group lending failed for several reasons, but foremost was the inability of potential borrowers to form a group. In Bangladesh, where poverty 
rates and population density are much higher than the those in the United States, potential borrowers can more readily find other entrepreneurs. However, a close network of social ties among the poor does not exist in rural Arkansas. In response to this problem, Good Faith Fund personnel established a mandatory six-week training program for individual new members and then created groups from the training programs. These newly formed groups of relative strangers lacked the social cohesion to enforce contract payments, unlike group members in rural Bangladesh, who often live in the same village and have family/community histories together. Consequently, group lending was slowly phased out of the Good Faith Fund. Today, the Good Faith Fund focuses mainly on career training through their Business Development Center and Asset Builders program. They have also found a niche in loaning larger amounts of money to small- and medium-sized enterprises that are underserved by the commercial banking center. These loans provide the same service, but at $\$ 100,000$ or more, they can hardly be considered "micro" credit.

\section{THE EVIDENCE ON MICROFINANCE}

In this section, we review some of the important questions on microfinance. Our assessment is based on numerous studies, technical surveys, and newspaper reports on microfinance. The attempt here is to be illustrative rather than provide a comprehensive review of microfinance.

\section{Is Microfinance a Desirable Alternative to Informal, Exploitative Sources of Finance?}

The spread of microfinance and the success of MFIs in various countries around the world prompts a question: Who served the poor before the microcredit revolution? It is well known that conventional banks, which act as creditors to most entrepreneurial activity in the modern world, have largely avoided lending to the poor. Instead, credit to the poor has been provided mostly by local moneylenders, often at usurious rates. Conse- quently, moneylenders are typically perceived as being exploitative, taking advantage of poor villagers who have no other recourse to loans. Therefore, it is not surprising that microfinance has been welcomed by most as an alternative to the abusive practices of village moneylenders. However, this common perception requires a more careful study: Why don't mainstream banks lend to the poor? In the banks' absence, do local moneylenders have monopoly power? More importantly, are these high interest rates charged by moneylenders welfare reducing?

We begin by listing the difficulties that arise in lending to the poor. First, early studies believed that poor people often lack the resources needed to invest their borrowings to the most productive use. In short, the poor borrow mostly to finance consumption needs (Bhaduri, 1977; Aleem, 1990). Second, even if loans could be earmarked for investment purposes, commercial banks would find it difficult to lend: Lack of credit histories and documented records on small entrepreneurs or farmers make it difficult for the bank to assess the creditworthiness of the borrower. Finally, there is the inability of the poor to post collateral on the loans. This reduces the bank's recourse to a saleable asset once the borrower defaults on the loan. Therefore, it is not difficult to see why commercial banks have avoided lending to the poor.

On the other hand, it is believed that local moneylenders could mitigate the problems faced by outside banks in lending to the poor. Local moneylenders are arguably better informed of borrower quality and have more effective means of monitoring and enforcing contracts than outside banks. In short, because of their social ties, information, and location advantage, these moneylenders are in a unique position to lend to the poor. Some observers argue that usurious interest rates in these markets can be explained by this "monopoly" that the local moneylenders enjoy. Several researchers have studied the market structure of rural credit markets in developing countries. Some argue that rural credit markets are more competitive than previously imagined because there is free entry for local moneylenders if not outside banks. While there is no broad consensus yet, most observers believe that despite 
free entry in these markets, moneylenders often enjoy some form of local monopoly power (in the manner of monopolistic competition), at least in the short run.

However, there are other reasons why moneylenders charge high interest rates. First, moneylenders have to compensate for the high transaction costs of issuing and servicing a small loan. Second, some observers believe that these funds have high "opportunity costs"- that is, moneylenders can earn high returns by investing in their own farms. Finally, and this is despite their local informational advantage, moneylenders face some of the same problems as commercial banks in identifying risky borrowers and securing collateral, particularly in poor rural areas. A simple numerical example helps illustrate this result ${ }^{11}$ : Consider two lenders with the same cost of funds. Suppose now that the first lender operates in a prime market where borrowers faithfully repay all of their loans at 10 percent, giving him an expected 10 percent return. However, the second lender operates in a poor rural market where borrowers arguably have a higher rate of default, say 50 percent. ${ }^{12}$ Consequently, her expected net return is thus $[(1+$ interest rate $) *(1-$ probability of default) -1$]$. Therefore, for the second moneylender to earn the same 10 percent return, she must charge an interest rate equal to 120 percent: $(1+120 \%) *(1-50 \%)-1=10 \%$. This is not to say that some moneylenders don't engage in price setting, but it does give a simple example in which a moneylender can be competitive but still charge extremely high interest rates.

Do moneylenders reduce welfare because they charge high interest rates? To the extent that borrowers willingly accept these loan contracts, the answer is no. ${ }^{13}$ These loan contracts do generate a positive surplus ex ante. That is, only those borrowers who expect to generate a rate of return from their investment that is higher than that

\footnotetext{
${ }^{11}$ This example in Armendáriz de Aghion and Morduch (2005) is drawn from the early work of Bottomley (1975).

${ }^{12}$ Of course, Yunus believes that this wrong assumption is the root of all the problems that the poor have in obtaining credit.

${ }^{13}$ Bhaduri (1973) points to some degree of coercion in rural credit markets, particularly in situations where landlords double as moneylenders.
}

charged by the moneylender will enter into these contracts. Clearly, this situation can be improved upon by offering lower rates: This would allow more borrowers-i.e., those who expect to generate a lower rate of return on their investment-to enter into loan contracts. However, this does not mean that a high interest rate per se reduces welfare. On the contrary, getting rid of moneylenders or preventing them from offering loans at these high rates can be welfare reducing; in their absence, entrepreneurs with the highest returns on their projects have no recourse to loans.

In contrast, MFIs can often offer lower interest rates than local moneylenders because of their higher efficiency in screening and monitoring borrowers, which results from both their economy of scale (serving more borrowers) and their use of joint liability lending mechanisms. This lowers the MFI's cost of lending relative to that of the local moneylender. To the extent that MFIs can provide loans at a lower rate than moneylenders, enabling more and more borrowers to enter the credit market, is an argument for both the efficiency (because of the reduced cost of funds) and welfare enhancement (because of an increase in the borrower pool) of microfinance.

\section{How High are the Repayment Rates for MFIs?}

This is widely regarded as the greatest achievement of microfinance. Many MFIs report high rates of repayment, often greater than 90 percent. These claims have driven considerable academic interest in why and how microfinance works. Furthermore, these repayment rates are widely cited in popular media (Business Week, July 9 and 16, 2007; Wall Street Journal, September 23, 2007) and have been one of the reasons for the recent interest generated by microfinance in financial markets worldwide. Although the theories of joint liability contracts, progressive lending, ${ }^{14}$ frequent repayments, and flexible collateral adequately explain these high rates of repayment, Morduch (1999) raises the important issue of

\footnotetext{
${ }^{14}$ Progressive lending is a type of dynamic incentive in which access to larger amounts of credit becomes available after each successfully repaid loan.
} 
validation. Because many of these repayment rates are self reported, it is important to understand the methodology used to calculate these repayment rates.

Morduch studies the repayment rates for the Grameen Bank for the 10-year period of 1985 to 1996. During this period, Grameen's average loan portfolio grew from $\$ 10$ million to $\$ 271$ million and membership expanded more than 12-fold to include 2.06 million members in 1996. For this decade, Grameen reports an average overdue rate of only 1.6 percent. ${ }^{15}$ Morduch's contention is that the Grameen Bank does not follow conventional accounting practices and calculates the overdue rates as the value of loans overdue (for more than one year) divided by the current portfolio, instead of dividing by the size of the portfolio when the overdue loans were issued. Because the size of the loan portfolio expanded 27-fold during this 10-year period, the loan portfolio is significantly larger at the end of any one year than at the beginning. Morduch finds the adjusted average default rate to be 7.8 percent for the same 10 -year period. He makes the point that "the rate is still impressive relative to the performance of government development banks, but it is high enough to start creating financial difficulties" (Morduch, 1999, p. 1590).

As for these financial difficulties, Morduch then focuses on reported profits, taking special care to examine the provision of loan losses. He finds that the bank is slow to write off bad loans, dropping only a modest 3.5 percent of its portfolio every year, again overstating the amount of profit. He calculates that instead of posting a total of $\$ 1.5$ million in profits, the bank would have instead lost a total of \$18 million. The implications to Morduch's findings are as follows: In the early 1990s, to operate without subsidies, the Grameen Bank would have had to raise interest rates on its general product from 20 percent to 50 percent, and this would have raised the aver-

\footnotetext{
${ }^{15}$ In comparison, nonperforming loans averaged between 1 and 1.5 percent for all U.S. commercial banks for the decade of 1995 to 2005. (Source: Federal Financial Institutions Examination Council.) Braverman and Gausch (1986) found that government credit programs in Africa, the Middle East, Latin America, South Asia, and Southeast Asia all had default rates between 40 and 95 percent.
}

age interest rate on all products to 32 percent. Morduch is careful to point out that it is unknown whether or not borrowers would defect, because for most borrowers the alternative is either no loan or an even higher interest rate on loans from a moneylender.

Although there is an apparent disagreement between Morduch's adjusted rates of repayment and the Grameen Bank's self reported rates, this alone does not mean that Grameen is a financial failure. In one case, the modest write-offs of bad loans offer proof of Yunus's organizational commitment to the poor and the belief that, given time, they will repay a loan. The since-implemented Grameen II Bank builds on this concept and allows borrowers to restructure a loan into smaller payments or to take a scheduled amount of time off, rather than default. Yunus describes the difference: "[The] overarching objective of the conventional banks is to maximize profit. The Grameen Bank's objective is to bring financial services to the poor, particularly women and the poorest and to help them fight poverty, stay profitable and financially sound. It is a composite objective, coming out of social and economic visions." Given that the Grameen Bank's focus is largely on social objectives and not profit maximization, some have argued that it is not obligated to adopt standard accounting procedures. What is important is that Grameen is among the few transparent microfinance organizations and researchers have been able to review and evaluate their financial statements.

An important consideration here is that MFIs are known to charge considerably higher rates compared with similar loans from conventional banks. In their celebrated work, Stiglitz and Weiss (1981) showed that the high interest rate that a lender charges may itself adversely affect repayment rates by either discouraging creditworthy borrowers (adverse selection) or tempting the borrowers to opt for riskier projects (moral hazard). Consequently, the coexistence of high repayment rates (around 95 percent) and higher interest rates (a 30 to 60 percent interest rate is common) in microfinance has "puzzled" economists.

One explanation offered by some economists is that MFIs face an inelastic demand for loans. 
However, in a recent empirical study on the SafeSave program in Dhaka slums, Dehejia, Montgomery, and Morduch (2005) show that the elasticity of demand for microcredit may be significantly negative even though certain groups of borrowers (particularly the wealthier ones) do not reduce their demand when faced with higher interest rates. However, Emran, Morshed, and Stiglitz (2006) offer a more promising explanation for this puzzle. Departing from the traditional focus on credit markets in studies of microfinance, the authors examine the implications of missing or imperfect labor markets for poor women in developing countries (the typical customers of MFIs in Bangladesh). Emran, Morshed, and Stiglitz (2006, p. 4) demonstrate "the critical role played by the structure of the labor market in making the small-scale household-based investment projects 'credit worthy' in the face of very high interest rates, especially for the poor households with little or no collaterizable assets."

\section{Is There More to Microfinance than Group Lending or Joint Liability Contracts?}

The success of microfinance in generating high repayment rates led many economists to investigate the reasons behind this success. The mid-to-late 1990s witnessed a large increase in the number of journal articles on group lending contracts, as economists sought to explain how microfinance "succeeded" where traditional forms of lending had failed. Joint liability contracts were seen as the break from traditional lending mechanisms and economic theory was used to readily explain how these contracts helped to improve repayment rates. The growth of the literature on group lending contracts in the mid-1990s offers the impression that all MFIs operate as such, but the reality is that MFIs use a variety of lending techniques, such as dynamic and progressive loans, frequent repayment schedules, and nontraditional collateral to ensure high repayment rates among poor, underserved borrowers. These mechanisms were either introduced independently or in conjunction with joint liability programs such as Grameen's and in many cases operate alongside group contracts. Practitioners and theorists alike have now realized that these mechanisms can operate with individual contracts and in certain cases (e.g., in areas of low population density) offer better repayment results than group lending schemes.

The mechanism of progressive lending guards against the borrower's strategic default at the end of a loan cycle, because by definition she has little or no collateral to be seized in the event of default. Instead, MFIs have offered small initial loans, with the promise of future credit for timely repayment. The offer of future credit serves as a powerful incentive for a micro-entrepreneur trying to grow her business. In this scenario, a borrower will default only if her current income is greater than her future expected profits. With a small initial loan for a beginning entrepreneurial venture, this is unlikely. To further increase the likelihood of repayment, MFIs use dynamic lending, in which the size of the loan is gradually increased with each successive loan repayment. Now, the expected future profits are almost certainly greater than current earned income because the size of the loan continues to grow.

Another mechanism used by MFIs is that of frequent repayments, which often begin even the week after the loan is disbursed. By requiring small repayments before the business venture has reach maturity, MFIs are essentially requiring that borrowers have a second source of income and, hence, borrow against their current consumption. This allows MFIs to screen against high-risk borrowers from the beginning because borrowers will be able to repay the loan even if their venture fails. Indeed, weekly repayments give the borrowers and lenders the added benefit of discovering problems early. Armendáriz de Aghion and Morduch (2005) also suggest that frequent repayments provide better customer service, contrary to the belief that more repayments raise the transaction costs for the borrower by requiring more travel to and from payment centers. Instead, frequent repayments help borrowers with savings constraints such as seasonality of income, family members dropping by to borrow funds, or discretionary spending by one or more of the family members. When coupled with dynamic incen- 
tives, frequent loan repayments begin to resemble savings deposits that will be paid with interest (the graduated size of the next loan). This allows families to break free of certain savings constraints (such as those noted above) because the loan is paid each week, before the money can be spent on anything else.

The final mechanism is the requirement of nontraditional collateral, which was introduced by banks such as Bank Rakyat Indonesia (BRI). This feature breaks from the commercial practice that collateral submitted must have a resale value equal to the loan. In a group lending contract, joint liability often serves as collateral, but BRI operates on the "notional value" of an item and allows collateral to be any item that is important to the household, regardless of market value. This may include the family's sole domestic animal, such as a cow, or it may be land that is not secured by title. Neither item could be sold for much of a profit without significant transaction costs to the bank, but both items would be even more difficult and costly for the family to do without.

Armendáriz de Aghion and Morduch (2000) offer evidence of the success of individual loans that use progressive/dynamic incentives, frequent repayments, and nontraditional collateral to guarantee a loan. Using data from Eastern Europe and Russia, they demonstrate that individual loans can generate repayment rates greater than 90 percent (and above 95 percent in Russia). In industrialized settings, borrowers are more likely to face more competition, making it more costly to form a borrowing group. In this scenario, loan products will go to different entrepreneurs, with different expected payoffs-hence, necessitating different loan amounts. A group contract can be inefficient because it imposes a ceiling on the loan size equal to that given to the smallest member of any potential group. They conclude by suggesting that in areas that are relatively industrialized, individual loan models may perform better than traditional group lending models.

\section{Is Microfinance an Important Tool for Poverty Alleviation?}

Microfinance started as a method to fight poverty, and although microfinance still fulfills this goal, several institutions have sought to make a distinction between the "marginally poor" and the "very poor." The broadest definition distinguishing these two groups comes from the Consultative Group to Assist the Poorest (CGAP), which defines the poor as individuals living below the poverty line and the poorest as the bottom half of the poor. The World Bank estimates that in 2001, some 1.1 billion people had consumption levels below $\$ 1$ and another 2.7 billion lived on less than $\$ 2$ per day. ${ }^{16}$ As microfinance continues to grow, questions have started to focus on who is the optimal client. Should microfinance target the marginally poor or the extremely poor?

Morduch (1999) tries to answer this question by considering two representative microfinance clients, one from each poverty group described above. The first client belongs to a subsidized microfinance program and her income is only 50 percent of the poverty line. The second client belongs to a financially sustainable program that accordingly charges higher interest rates. To ensure repayment of the loan at the higher rate, the second borrower is chosen to be marginally poor, that is, with an income of 90 percent of the poverty line. Using the widely used "squared poverty gap" (Foster, Greer, and Thorbecke, 1984) measure of poverty, Morduch suggests that a dollar increase in income for the very poor borrower has a five times greater impact than the same dollar for the marginally poor borrower.

This simple example would suggest that, in terms of poverty alleviation, MFIs should focus on the poorest borrowers first, but this is not always the case. As MFIs seek to become financially independent, they find themselves serving only the marginally poor. This is an important distinction between Grameen and Banco Sol of Bolivia: The latter's emphasis is on returning a profit, and alleviating poverty is seen only as a secondary goal. Not surprisingly, Banco Sol charges higher interest rates, ${ }^{17}$ does not rely on

\footnotetext{
${ }^{16}$ World Bank, "Poverty Analysis"; data can be viewed at http://web.worldbank.org.

17 Annual interest rates average between 12 and 24 percent and can be anywhere from 1 to 60 months in length (120 months for a housing loan). The data are from Banco Sol, accessed 7/27/07; www.bancosol.com.bo/en/intro.html.
} 
subsidies, and at the end of 2006 posted returns on equity of 22.8 percent. $^{18}$

This apparent dichotomy between financial independence and poverty alleviation also gets to the heart of a different problem. At what point does a successful MFI begin to look like a regular bank? If the MFI successfully serves poor clients, then those clients should be able to use their loans to lift themselves out of poverty. Because of the nature of progressive and dynamic loans, successful borrowers earn access to larger loans, helping them break free of poverty even faster.

The Grameen Bank has found a way to make this dichotomy work for them and now uses their economy of scale to create a financially independent bank without raising interest rates. In 1995, the Grameen Bank decided not to request any more funds from donors and instead began to fund the bank from collected deposits. With more than two decades of successful borrowers behind them, Grameen has had a chance to build up savings deposits slowly, to the point that it is now self-sustainable, based on the amount of funds provided by members. In a rough sense, it is now the more-successful poor that are subsidizing new clients. This is a significant step, especially considering that, from the decade of 1985 to 1996, Armendáriz de Aghion and Morduch (2005) calculate that Grameen accepted \$175 million in subsidies, including both direct donations and "soft" donations such as soft loans, implicit subsidies through equity holdings, and delayed loan loss provision.

\section{Is Microfinance Sustainable or Even Profitable?}

With all of the positive publicity surrounding microfinance, it may be surprising to learn that not all MFIs are sustainable or able to return a profit. Despite their rapid growth and sound operations based on strong theoretical platforms (such as using group loans, dynamic incentives, and frequent repayments), less than half of all

\footnotetext{
${ }^{18}$ MIX Market financial data are from BancoSol, accessed 8/2/07; www.mixmarket.org/en/demand/demand.show.profile.asp? token=\&ett=280.
}

MFIs return a profit and most still require the help of donors and subsidies. A lack of financial sustainability doesn't necessarily indicate a failing MFI, but rather raises questions about the mission and direction of that particular MFI. Even with subsidies, many MFIs remain the most costeffective method to alleviate poverty; and, as we argued previously, subsidies can help change the profile of the targeted client from the poor to the extremely poor.

For an MFI to be sustainable can mean one of two things: The organization can be operationally sustainable or it can be financially sustainable. An MFI that is operationally sustainable raises enough revenue to cover the cost of operating the business-paying loan supervisors, opening branch offices, etc. Subsidies might still be used to issue loans or cover defaulted loans. An institution that is financially sustainable does not require any subsidized inputs or outside funds to operate. Instead, it raises money through its lending operations. The MicroBanking Bulletin (2003) surveyed 124 MFIs with a stated commitment to becoming financially sustainable. In their survey, the Bulletin found that only 66 operations were sustainable, a rate just slightly above 50 percent. As Armendáriz de Aghion and Morduch (2005, p. 232) note, all 124 programs asked for help in managing their accounting standards and, hence, "in terms of financial management, [these 124 programs] are thus skimmed from the cream of the crop." Similar sustainability data do not exist for the other 2,000+ MFIs; but, without similarly strong commitments to financial sustainability, the percentage of sustainable operations is likely to be much lower than 50 percent.

Subsidized credit is financed in a variety of forms, some of which have been discussed briefly with the Grameen Bank example. MFIs also secure funds from donors, many of whom want to alleviate poverty but have not seen strong returns in the nongovernmental organization (NGO) or government sector. For many, donations and subsidies are intended as a method to get MFIs started. But without any accountability or empirical research, it is difficult for donors to decide at what point an MFI should forgo its dependence on outside funds. Lacking in this debate is a clear under- 
standing of how subsidies affect the supply and demand of loans. Without subsidies, interest rates may rise; and, as standard demand theory suggests, fewer loans will be requested. Moreover, rising interest rates without subsidies may exclude poorer projects, thus raising average returns. But, they may also increase the moral hazard problem; at higher interest rates, only risky borrowers apply for a loan, thus increasing the default rate and lowering returns. Finally, it is unclear what affect subsidized lenders have on the overall credit supply. Do they segment the credit market while serving the very poor or do they squeeze out other lenders, reducing overall efficiency for the market?

In some instances, government institutions collaborate with local MFIs; but, more often than not, government organizations and MFIs are at odds with one another, despite the fact that both share the stated goal of reducing poverty. A prime example of the failure of government subsidized initiatives in the market for microcredit is the Integrated Rural Development Program (IRDP), which allocated credit based on social targets in rural India, giving 30 percent of credit to socially excluded groups and 30 percent to women.

Armendáriz de Aghion and Morduch (2005) report that between 1979 and 1989 IRDP offered over $\$ 6$ billion in subsidized credit but generated loan repayment rates below 60 percent, with only 11 percent of borrowers taking out a second loan. During the same decade, the Grameen Bank also accepted subsidies in a variety of forms, but did not change their lending model to include social targets. During this time, the Grameen Bank saw its membership grow to half a million members, with repayment rates above 90 percent. The experience of the Grameen Bank and IRDP during the late 1970s and early 1980s is important because of the similarities between regions. Both Bangladesh and India are densely populated, rural, agrarian economies with high rates of poverty. Therefore, it is likely that the Grameen Bank's comparative success during this period is indicative of a more efficient lending model rather than variances in their lending environment.

In sum, even if many MFIs are not financially sustainable, the microfinance movement may still be the best per-dollar investment for alleviating poverty. Further research is needed to show whether financial sustainability is even a desired objective, and future work could help understand how different subsidy mechanisms can best balance financial sustainability with the desired social objectives.

\section{Could Competition Among MFIs Lead to Better Results?}

At first glance, standard economic theory suggests that competition should improve the performance of MFIs and lead to better service and lower interest rates. With such a large poor population and high rates of growth, there is also a large market to support more MFIs. Historically, though, competition has failed to increase services and often decreases the rate of repayment. When clients have access to alternative sources of credit, MFIs lose the leverage they gain from dynamic incentives and progressive loans (i.e., future loans are contingent on repayment).

During the late 1990s, Bolivia and Banco Sol experienced a microfinance crisis. As the success of Banco Sol increased and commercial banks began to see the profitability in an MFI model, competition increased. General economic theory suggests that competition is inherently good, but for the early MFIs, competition reduced efficiency by weakening the incentives: As credit options increased for borrowers, the incentives inherent in a dynamic or progressive loan became weaker. This proved difficult for Banco Sol, whose model relies on group lending and dynamic incentives. The competition mainly came from Acceso FFP, a Chilean finance company that paid its employees on an incentive system. Within three years, Acceso had 90,000 loans, and Banco Sol lost 11 percent of its clients. Regulated MFIs in Bolivia saw their loan overdue rates increase from 2.4 percent to 8.4 percent in just over two years. Because of the increased competition, Banco Sol saw its return on equity fall by 20 percentage points to only 9 percent in 1999 (Armendáriz de Aghion and Morduch, 2005, p. 127).

In their study of 2,875 households from 192 villages in Thailand, Ahlin and Townsend (2007, 
p. F43) reach a similar conclusion. They note that, with increased access to credit, borrowers do not respond to dynamic incentives. Moreover, strong social ties, such as the clustering of relatives in a village, can also lower repayment rates in the same manner of competition. In their words, "this result has not been seen in the previous empirical research, nor focused on in the theoretical models."

In the early years of competition in the microfinance sector, MFIs struggled to maintain a credible threat of denying future credit on default. In recent times, however, new regulation has helped to promote competition in Bolivia as lenders started to share more information on borrowers. By law, Banco Sol and other regulated financial intermediaries are now required to report the name and national identification number of delinquent borrowers to the Superintendent of Banks and Financial Institutions. This information is available to all financial intermediaries through both formal and informal agreements. This agreement helped to strengthen the threat of dynamic incentives, and, as a result, competition among lenders has led to an increase in their client base.

\section{Does Microfinance Have Any Social Impact in Terms of Female Empowerment and Education?}

Any review of microfinance is incomplete without a discussion of its impact on women. The Microcredit Summit Campaign Report (2000) lists over a thousand programs in which 75 percent of the clients were women. Yunus (2003) recounts the initial difficulties overcoming the social mores in rural Bangladesh and lending to women in this predominantly Islamic nation. However, his efforts were rewarded and 95 percent of the Grameen Bank's current clients are women.

This focus on women follows largely from Yunus's conviction that lending to women has a stronger impact on the welfare of the household than lending to men. This has been confirmed by a large volume of research on microfinance. In countries where microfinance is predominant, country-level data reveal signs of a social trans- formation in terms of lower fertility rates and higher literacy rates for women. Pitt and Khandker (1998) show that loans to women have a positive impact on outcomes such as children's education, contraceptive use, and the value of women's non-land assets. Khandker (2005) finds that borrowing by a woman has a greater impact on per capita household expenditure on both food and non-food items than borrowing by a man. Among other things, this also improves nutrition, health care, and educational opportunities for children in these households. Smith (2002) validates this assertion using empirical data from Ecuador and Honduras to compare microfinance institutions that also offer health services with institutions that offer only credit. He notes that, "in both countries, health bank participation significantly raises subsequent health care over credit-only participation." In particular, he found that participation in MFIs that offer health services reduces the tendency to switch to bottle feeding as incomes rise. He notes that breast-feeding children under age two is a key health-enhancing behavior.

A pro-female bias in lending works well for the MFIs. Practitioners believe that women tend to be more risk averse in their choice of investment projects, more fearful of social sanctions, and less mobile (and therefore easier to monitor) than men-making it easier for MFIs to ensure a higher rate of repayment. Various studies from both Asia and Latin America have shown that the repayment rates are significantly higher for female borrowers compared with their male counterparts.

However, critics have argued that microfinance has done little to change the status of women within the household. A much-cited paper by Goetz and Gupta (1996) points to evidence that it is mostly the men of the household and not the women borrowers who actually exercise control over the borrowings. Moreover, microfinance does little to transform the status of women in terms of occupational choice, mobility, and social status within the family. Therefore, microfinance hardly "empowers" women in any meaningful sense. Although this may truly be 
the case, there is no denying the fact that microfinance has provided heretofore unrealized working opportunities for women with limited skills in traditional activities.

\section{Can the Microfinance Experiment Be Successfully Replicated Anywhere in the World?}

Although the microfinance revolution has recorded success in most developing countries of the world, it has achieved little success in some of the more developed nations. The most notable example here is the Good Faith Fund in Arkansas, where microfinance has failed to deliver the same rapid growth and poverty alleviation as it has in the developing world. This seems reasonable given the relatively smaller percentage of those living in poverty and the much larger safety net afforded the poor through welfare and unemployment programs. As Yunus (2003, p. 189) states, "In the developed world, my greatest nemesis is the tenacity of the social welfare system...[M]any calculate the amount of welfare money and insurance coverage they would lose by becoming self-employed and conclude the risk is not worth the effort." Yunus correctly addresses a motivating factor for the relatively weak success of microfinance in the United States, but studies have found other reasons why microfinance has failed to deliver: e.g., a lack of entrepreneur opportunities for the poor, lack of group structure, and the multitude of options facing the U.S. poor.

Why Did Microfinance Initiatives Fail in the United States? In their study of U.S. microfinance, Edgcomb, Klein, and Clark (1996) find that micro-enterprise accounts for only 8 to 20 percent of all jobs-because of the availability of wage jobs and public assistance. When compared with the 60 to 80 percent of jobs supplied by micro-enterprise in the developing world, the pool of potential microfinance beneficiaries in the United States is substantially smaller. Schreiner and Woller (2003) make the point that the characteristics of the poor are different in the two regions. In the developing world, jobs are relatively scarce and hence the unemployed are more likely on average to include individuals that are highly skilled or better motivated to become entrepreneurs. In contrast, in the United States, where poverty is much less prevalent, most individuals with the aforementioned characteristics can find jobs. Furthermore, the amount of small business regulation in the United States poses problems; a micro-entrepreneur must know their proposed business but must also understand local and federal tax laws and regulations. To compete with much larger national markets, small business owners must further understand and excel at marketing their products in both local and larger markets. The lack of highly skilled or better-motivated workers among the poor in the United States, combined with the higher entry costs for successful micro-enterprise, makes successful microfinance initiatives more difficult. Schreiner (1999) finds that, in absolute terms, only one person in a hundred was able to move from unemployment to self-employment through micro-enterprise.

Taub (1998) offers a slightly different explanation: He found that the markets for the borrowers differed between regions. In Bangladesh, most small entrepreneurs engage in goods-producing activities that, when combined with their small local markets, offers an almost immediate stream of revenue. This feature allows the Grameen Bank and others to require weekly repayments, which is often cited as a primary reason for their high repayment rates. In the United States, most entrepreneurs engage in service-producing activities because it is difficult to compete against the economies of scale in goods production and distribution within the U.S. market. These service businesses provide a relatively unreliable source of income, particularly in the early stages. This risk, combined with the safety net afforded to the poor through welfare, discourages many potential entrepreneurs from starting a new venture. In support of this point, Taub found that the likely borrower comes from a family with at least one source of steady income, so that their new venture is unlikely to substantially hurt their family resources.

In the late 1980s, the Good Faith Fund demonstrated the difficulty of forming a cohesive group 
structure to enforce joint liability loans. Schreiner and Woller (2003) offer four basic failures of group formation in the United States. First, they suggest that the impersonal nature of U.S. market interactions reduces the need for social reputations and hence the group loses the ability to punish delinquent borrowers. Second, the U.S. poor are diverse and hence it is difficult to find other poor potential entrepreneurs to guarantee a group loan. In U.S. markets, there is also a limit to the potential number of small-business ideas. In developing countries, a group of borrowers may all enter the basket-making market with success because of the much larger local economy. The group guarantees the loan but also offers advice to help succeed in the market. In the United States, the demand for micro-businesses is much smaller and diverse groups of people must start diverse business ventures. There is little value to the group outside of a loan guarantee because group members don't share the same risk to their businesses. Third, defaults are often not enforced in group settings, as found by Hung (2003). Finally, groups often break down in the United States because the poor have access to other forms of credit. This credit may be more attractive because it doesn't require the transaction costs of dealing with a group.

For the United States, pure Grameen-style group lending schemes have failed to deliver substantial results, but that is not to say they have not benefited the poor. Rather, microfinance operations in the United States have often switched to individual lending operations that require borrowers to attend mandatory small business training programs or offer loans to attend specialized schooling for particular professions. A fundamental difference is that microfinance in the United States helps place the poor into existing wage-earning jobs rather than create new jobs. The additional training substantially raises costs to the point that many U.S. MFIs are not selfsustaining, instead relying on grants and subsidies. Edgcomb, Klein, and Clark (1996) found that the average cost to make and service a loan was $\$ 1.47$ per dollar lent, with a range of costs from $\$ 0.67$ to $\$ 2.95$. Without charging usurious interest rates, it can be difficult to earn such a similarly high return, particularly with the smaller microfinance market. Taub (1998) reports that from 1989 to 1992, the Good Faith Fund averaged only 18 new loan customers per year. ${ }^{19}$ In the following years, the average number of new loan customers rose into the mid 20s, before a change in management and change in focus substantially reduced those numbers. With small loans, averaging just $\$ 1,600$ per year for the first four years, it became impossible for the Good Faith Fund to even come close to matching the combined staff salaries of $\$ 450,000$.

Due in part to these high-cost structures, Bhatt, Tang, and Painter (2002) found direct evidence that nearly a third of MFIs started in California in 1996 had ceased to exist by 1998. Instead of focusing on becoming self-sufficient, Schreiner (2002, p. 82) argues for more quantitative evaluation of MFIs. He claims that "the dirty secret in micro-enterprise is that few evaluations are really tests...[E]valuations were funded and conducted by people who already believed that micro-enterprise was worthwhile." Schreiner thus concludes that a main goal in helping alleviate poverty should be to evaluate the efficiency of MFIs and, if need be, reallocate resources to other training programs that specialize in poverty alleviation, not economic development.

\section{THE FUTURE OF MICROFINANCE}

The number of MFIs has been growing steadily, and the top 100 MFIs are increasing their client base at a rate of 26 percent per year. ${ }^{20}$ To fund this spectacular growth, MFIs have turned to a variety of sources, many of which rely on funding from local sources to guard against foreign currency risk. MFIs are currently moving into the international market and confronting challenges such as developing standard rating methods; guarding against foreign currency risk and country risk; and meeting the large volume

\footnotetext{
${ }^{19}$ At the time of Taub's study, population density in Bangladesh was 814 per square kilometer, while the population densities of Arkansas counties served by the Good Faith Fund were only 36, 9, 8, 9.1, and 10.33 per square kilometer (Jefferson, Lincoln, Desha, Chicot, and Ashley counties, respectively).

${ }^{20}$ MIX Market analysis of top 100 MFIs; www.mixmarket.org.
} 
requirements for an international offering. But, according to Reddy (2007) of Accion International, "Many believe that savings mobilized from local depositors will ultimately be the largest source of capital for microfinance. Foreign capital provides 22 percent of funding for the 'Top 100' MFIs, but savings is the first source of capital, representing 41 percent of all assets in 2005." ${ }^{21}$ Many MFIs have a mandatory or suggested savings rate; and, for larger loans, MFIs will often require borrowers to deposit 5 percent of the loan back into a savings account. Some, but not all, have restrictions on when and how that money can be accessed.

Although not the main source of funding, foreign capital still represents a significant portion of current funding for the top 100 MFIs. As Elizabeth Littlefield of CGAP found, U.S. investment in foreign microfinance in 2006 was $\$ 4$ billion, which is more than double the 2004 total of $\$ 1.6$ billion. This funding comes from two main sources: international financial institutions and microfinance investment vehicles. To access this foreign investment, MFIs are beginning to use new vehicles of debt-structured finance, including collateralized debt obligations (CDOs) and securitization.

To date, one of the most well-known international debt issues was structured by Blue Orchard Finance in 2004. This deal, worth $\$ 40$ million, linked 90 investors with nine MFIs in Latin America, Eastern Europe, and Southeast Asia. The main innovation of the Blue Orchard deal was the introduction of a tiering system (of five tranches) that allowed for different risk appetites among investors. Microfinance is also beginning to raise money in the equity market, through organizations such as Accion Investments, which has invested \$12.4 million in five institutions (Reddy and Rhyne, 2006).

In 2006, the first securitized microfinance receivables went on the market from the Bangladesh Rural Advancement Committee (BRAC). BRAC is an NGO that lends money to the extremely poor, focusing mainly on offering women credit to develop their own income-

\footnotetext{
${ }^{21}$ Data taken from MIX Market analysis of the top 100 MFIs; www.mixmarket.org.
}

generating activities. The transaction was structured by RSA Capital, CitiGroup, the Netherlands Financing Company, and KfW Bank of Germany and has securitized $\$ 180$ million in receivables over a period of six years.

According to CitiGroup, 65 percent of the loans are to the extremely poor, who borrow from $\$ 50$ to $\$ 100$. BRAC offers three loans, based primarily on the land holdings of the borrower. For those with less than one acre of land, borrowers can obtain from $\$ 50$ to $\$ 500$ at a flat 15 percent rate, payable over one year through 46 weekly installments. The marginally poor, those who own more than one acre of land and are involved in agricultural enterprise, can qualify for loans between $\$ 166$ and $\$ 833$ with a flat 15 percent interest rate. This product must be repaid in equal monthly installments, with a 12- or 18-month horizon. Finally, BRAC offers larger loans to entrepreneurs to start their own business. These loans are monthly products $(12,18$, or 24 months) with a 15 percent interest rate. ${ }^{22}$ BRAC employs a dynamic lending scheme, wherein timely repayments guarantee future access to credit. This mechanism is similar to a joint lending liability, except in this case borrowers are liable to their future selves.

International Financing Review Asia honored the BRAC deal with the title of best securitization in Asia Pacific for 2006 because "one of the most impressive aspects of the transaction is the way that it deals with the sheer complexity of a dynamic pool that will contain about 3.3 million short tenor loans for which the average outstanding principal is around US\$95."23 The security was given an AAA rating from the local Bangladesh markets, with CitiGroup and Netherlands Financing Company each purchasing one-third of the certificates. The remaining onethird was split among CitiGroup Bangladesh and two local Bangladeshi banks.

This deal differs from the collateralized debt obligations that Blue Orchard Loans for

\footnotetext{
${ }^{22}$ See BRAC's economic development and microfinance information at www.brac.net/microfinance.htm.

${ }^{23}$ CitiGroup: "Innovative BRAC Microcredit Securitization honored in Bangladesh," accessed 1/16/07; www.citigroup.com/citigroup/ press/2007/070116b.htm.
} 
Development issued in April 2006, in which funding for 21 MFIs from 12 countries was packaged into a $\$ 99.1$ million commercial investment. The main difference between a CDO and securitization is that a CDO relies on the ability of the MFI to repay the loan, unlike a securitized loan that relies on the underlying borrowers to repay. A CDO is another vehicle to bring mainstream investors to microfinance, but is still limited by the ability to rate the creditworthiness of differing MFIs. To help with this issue, S\&P released a rating methodology for microfinance in June 2007. By applying a common methodology, S\&P will be able to send a stronger signal to potential investors about the quality of MFI investments. It is unclear yet whether the 2007 subprime mortgage meltdown in the United States will have an effect on investors' risk appetites for more collateralized securities and whether microfinance securities will be viewed as "subprime" loans.

Walter and Krauss (2006) argue that the opposite should be true-namely, that microfinance can reduce portfolio volatility-and their empirical tests show that microfinance institutions have a low correlation to general market movements. They suggest that this phenomenon is brought on by the continuous and diverse funding through international donor agencies and because micro-entrepreneurs may be less integrated into the formal economy. When markets enter a downturn, micro-entrepreneurs may experience a countercyclical effect, as consumers shift their consumption downward to cheaper goods.

Outside of international credit markets, microfinance has continued to receive grassroots support and popular media coverage. Organizations such as Kiva.org serve as intermediaries and connect individual donors with microentrepreneurs. Kiva.org allows individuals to choose a business, originate their own micro-loan, and in return receive electronic journal updates and payments from their borrower. Most loans are small, between $\$ 50$ and $\$ 100$ and have repayment terms from six months to a year, but the lender does not receive any interest on their loan. Rather, journal updates and progress reports serve as interest, letting lenders know that their money has been put to good use. At the end of the year, providers can start the cycle anew or withdraw. To date, 128,547 individuals have lent over \$12 million with a self-reported repayment rate greater than 99 percent. Popular media outlets such as the Wall Street Journal (September 23, 2007, August 21, 2007, October 21, 2006), New York Times (March 27, 2007, December 10, 2006), National Public Radio (September 7, 2007, June 19, 2007, April 6, 2007), and others have given Kiva.org frequent and broad exposure, making the microfinance movement as accessible to lenders as the Grameen Bank made microcredit accessible to borrowers.

\section{CONCLUSION}

With the recognition of the Nobel Peace Prize in 2006, Muhammad Yunus's vision of extending credit to the poor has reached a global level.

Microfinance is not a panacea for poverty alleviation; but, with committed practitioners, a wealth of theoretical work, and a surging demand for both international and individual investment, microfinance is a poverty-alleviation tool that has proven to be both effective and adaptable. Through innovations in group lending and dynamic incentives, MFIs have been able to successfully lend to those traditionally ignored by commercial banks, because of their lack of collateral and credit scores. The poor have responded in kind, by repaying their loans with significant repayment rates. As MFIs have grown and reached new clients, they have continued to innovate by offering individual loans, savings options, and life insurance and seeking new forms of capital in domestic and international markets. Microfinance has spread to five continents and hundreds of countries, yet its success in U.S. markets has been ill-defined, as lenders struggle with higher transaction costs of offering loans and starting micro-enterprises. As more and more MFIs become self-sufficient and continue to expand their client base, it will be the duty of all parties concerned with poverty relief to look for other ways to innovate. For now, microfinance remains a viable solution to economic development and poverty alleviation, both 
in Bangladesh and around the world. With more transparency from institutions and better rating standards, the influx of investment capital from international markets will continue to drive microfinance toward Yunus's goal of a povertyfree world.

\section{REFERENCES}

Ahlin, Christian and Townsend, Robert M. "Using Repayment Data to Test Across Models of Joint Liability Lending." Economic Journal, February 2007, 117(517), pp. F11-51.

Aleem, Irfan. "Imperfect Information, Screening, and the Costs of Informal Lending: A Study of a Rural Credit Market in Pakistan." World Bank Economic Review, September 1990, 4(3), pp. 329-49.

Armendáriz de Aghion, Beatriz and Morduch, Jonathon. "Microfinance: Beyond Group Lending." Economics of Transition, July 2000, 8(2), pp. 401-20.

Armendáriz de Aghion, Beatriz and Morduch, Jonathon. The Economics of Microfinance. Cambridge, MA: MIT Press, 2005.

Bhaduri, Amit. "A Study in Agricultural Backwardness Under Semi-feudalism." Economic Journal, March 1973, 83(329), pp. 120-37.

Bhaduri, Amit. "On the Formation of Usurious Interest Rates in Backward Agriculture." Cambridge Journal of Economics, December 1977, 1(4), pp. 341-52.

Bhatt, Nitan, Tang, Shui Yan and Painter, Gary. "Microcredit Programs in the United States: The Challenges of Outreach and Sustainability," in J. Carr and Z.-Y. Tong, eds., Replicating Microfinance in the United States. Washington, DC: Woodrow Wilson Center Press, 2002.

Bottomley, Anthony. "Interest Rate Determination in Underdeveloped Rural Areas.” American Journal of Agricultural Economics, May 1975, 57(2), pp. 279-91.

Braverman, Avishay and Guasch, J. Luis. "Rural
Credit Markets and Institutions in Developing Countries: Lessons for Policy Analysis from Practice and Modern Theory." World Development, October/ November 1986, 14(10/11), pp. 1253-67.

Dehejia, Rajeev; Montgomery, Heather and Morduch, Jonathan. "Do Interest Rates Matter? Credit Demand in the Dhaka Slums." Unpublished manuscript, March 2005.

Edgcomb, Elaine; Klein, Joyce and Clark, Peggy. "The Practice of Microenterprise in the US: Strategies, Costs, and Effectiveness.” Washington, DC: Aspen Institute, 1996.

Emran, M. Shahe; Morshed, A.K.M. Mahbub and Stiglitz, Joseph E. "Microfinance and Missing Markets.” Unpublished manuscript, October 2006.

Foster, J.; Greer, J. and Thorbecke E. "A Class of Decomposable Poverty Measures.” Econometrica, 1984, 52, pp. 761-66.

Ghatak, Maitreesh. "Screening by the Company You Keep: Joint Liability Lending and the Peer Selection Effect.” Economic Journal, July 2000, 110(465), pp. 601-31.

Ghatak, Maitreesh and Guinnane, Timothy. "The Economics of Lending with Joint Liability: Theory and Practice." Journal of Development Economics, October 1999, 60(1), pp. 195-228.

Goetz, Anne Marie and Gupta, Rina Sen. "Who Takes the Credit? Gender, Power, and Control Over Loan Use in Rural Credit Programs in Bangladesh." World Development, January 1996, 24(1), pp. 45-63.

Hung, Chi-kan Richard. "Loan Performance of GroupBased Microcredit Programs in the United States." Economic Development Quarterly, November 2003, 17(4), pp. 382-95.

Khandker, Shahidur R. "Microfinance and Poverty: Evidence Using Panel Data from Bangladesh." World Bank Economic Review, September 2005, 19(2), pp. 263-86.

MicroBanking Bulletin. "Focus on Savings," July 2003, No. 9, pp. 72-76; www.mixmbb.org. 


\section{Sengupta and Aubuchon}

Microcredit Summit Campaign Report 2000, 2000; www.microcreditsummit.org/campaigns/ report00html\#overview.

Morduch, Jonathan. "The Microfinance Promise.” Journal of Economic Literature, December 1999, 37(4), pp. 1569-614.

Pitt, Mark M. and Khandker, Shahidur R. "The Impact of Group-Based Credit Programs on Poor Households in Bangladesh: Does the Gender of Participants Matter?" Journal of Political Economy, October 1998, 106(5), pp. 958-96.

Reddy, Rekha M. "Microfinance Cracking the Capital Markets II.” InSight, May 2007, 22, pp. 1-17.

Reddy, Rekha M. and Rhyne, Elisabeth. "Who Will Buy Our Paper: Microfinance Cracking the Capital Markets?” Insight, April 2006, 18, pp. 1-19.

Rhyne, Elisabeth. Mainstreaming Microfinance: How Lending to the Poor Began, Grew, and Came of Age in Bolivia. Bloomfield, CT: Kumarian Press, 2001.

Schreiner, Mark. "Lessons for Microenterprise Programs from a Fresh Look at the Unemployment Insurance Self-Employment Demonstration." Evaluation Review, October 1999, 23(5), pp. 503-26.

Schreiner, Mark. "Evaluation and Microenterprise Programs in the United States." Journal of Microfinance, Fall 2002, 4(2), pp. 67-91.

Schreiner, Mark and Woller, Gary. "Microenterprise Development Programs in the United States and in the Developing World." World Development, September 2003, 31(9), pp. 1567-80.
Smith, Stephen C. "Village Banking and Maternal and Child Health: Evidence from Ecuador and Honduras." World Development, April 2002, 30(4), pp. 707-23.

Stiglitz, Joseph and Weiss, Andrew. "Credit Rationing in Markets with Imperfect Information.” American Economic Review, June 1981, 71(3), pp. 393-410.

Taub, Richard P. "Making the Adaptation Across Cultures and Societies: A Report on an Attempt to Clone the Grameen Bank in Southern Arkansas." Journal of Developmental Entrepreneurship, Summer 1998, 3(1), pp. 353-69.

Walter, Ingo and Krauss, Nicolas A. "Can Microfinance Reduce Portfolio Volatility?” Working paper, November 9, 2006; http://ssrn.com/abstract=943786.

Yunus, Muhammad. "Grameen Bank II: Designed to Open New Possibilities.” Grameen Bank, October 2002; www.grameen-info.org/bank/bank2.html.

Yunus, Muhammad. Banker to the Poor: MicroLending and the Battle Against World Poverty. New York: Public Affairs, 2003.

Yunus, Muhammad. "What Is Microcredit?" Grameen Bank, September 2007; www.grameen-info.org/bank/WhatIsMicrocredit.htm. 